\title{
RESISTING RETREAT: THE STRUGGLE FOR EQUITY IN EDUCATIONAL OPPORTUNITY IN THE POST-BROWN ERA*
}

\author{
Lia B. Epperson ${ }^{* *}$
}

\section{INTRODUCTION}

The late Supreme Court Justice Thurgood Marshall, founder of the NAACP Legal Defense Fund ("LDF"), and head of the legal team that litigated Brown v. Board of Education, ${ }^{1}$ knew well the challenges desegregation posed in a nation founded on a system of racial subjugation and white supremacy. A full thirty years after Brown, he acknowledged that:

Desegregation is not and was never expected to be an easy task. Racial attitudes ingrained in our Nation's childhood and adolescence are not quickly thrown aside in its middle years. . . . In the short run, it may seem to be the easier course to allow our great metropolitan areas to be divided up each into two cities — one white, the other black - but it is a course, I predict, our people will ultimately regret. ${ }^{2}$

In my work as a civil rights lawyer today, I clearly see that desegregation has not been an easy task. My education cases take me to towns like Gadsden, Alabama, where echoes of the Civil War still reverberate through the halls of school buildings and the steel of bridges over the mighty Coosa River-bridges from whose beams black men were lynched. ${ }^{3}$ In Gadsden, I litigate a school desegregation case filed more than three decades ago by my predecessors at LDF. The case is aimed at forcing compliance with the mandate of Brown that separate and unequal schools be eradicated. After decades of federal court supervision, one might assume schools in places such

\footnotetext{
* This article is based on a presentation at the Brown v. Board of Education Symposium held at the University of Pittsburgh School of Law on February 6, 2004. The author will present a more detailed exploration of the themes raised in this article in a forthcoming issue of the University of Pittsburgh Law Review.

** Director of Education, NAACP Legal Defense and Educational Fund, Inc.

1. Brown v. Bd. of Educ., 347 U.S. 483 (1954).

2. Milliken v. Bradley, 418 U.S. 717, 814-15 (1974) (Marshall, J., dissenting).

3. See, e.g., James Allen et Al., Without Sanctuary: Lynching Photography in America 86-87, 198 (2000) (depicting a crowd of whites observing the corpse of a lynched African-American man, severely beaten and stripped to long-johns, hanging over the Coosa River).
} 
as Gadsden have traveled further down the road to achieving educational equity for the town's black and white children.

In 2004, however, many children in Gadsden still attend a middle school named after Nathan Bedford Forrest, an uneducated, slave-owning Confederate general who was also the first Grand Wizard of the Ku Klux Klan. ${ }^{4}$ When my colleagues and I recently argued that black students who are required to attend classes in a school named after such a figure may feel alienated from their own school, school officials vociferously resisted in a manner that was startlingly similar to the sort of self-righteous resistance historically exhibited by most Southern districts in the wake of Brown. The reflection of our nation's history of slavery and apartheid is apparent in symbols like a local high school's mascot - a rebel soldier toting a gun-as well as in the very real disparities evident in the largely segregated schools. On one of my first visits to the public schools, I saw that many black children in this small Southern town studied in classrooms with broken desks, leaking roofs, and few supplies. Bathrooms in these majority-black schools often lacked sufficient toilet paper and soap. The chemistry lab in the majorityblack high school lacked running water and the necessary equipment to carry out the experiments listed in lesson plans. Students there have long had fewer opportunities to take the upper-level and specialized classes that are available in the town's other high schools, which make students more attractive candidates to competitive colleges and universities.

Unfortunately, the situation for children in Gadsden is not as unique as it should be. Districts across the country are experiencing similar patterns of segregation and inequities, both in facilities and in the curricular offerings generally made available to white students versus those made available to black or brown students. There seems to be little recognition, however, of the fact that the ideal of an American society with true educational equity has been thwarted at so many turns.

Although the story of Brown as ending state-mandated racial segregation in public schools is well-known throughout this country, the story did not end with the Supreme Court decision in 1954, nor did it end with its companion case one year later. ${ }^{5}$ Rather, there is a sordid history of a lengthy and protracted battle to see the mandate of this ground-breaking case implemented in Southern states and throughout the nation. In truth, the promise of Brown,

4. See, e.g., Howard Ball, A Defiant Life 3 (1998); Jack Hurst, Nathan Bedford Forrest (1994); Lynne Olson, Freedom's Daughters 340 (2001).

5. See Brown v. Bd. of Educ., 349 U.S. 294 (1955) (announcing that school districts must desegregate "with all deliberate speed"). 
so revolutionary at its inception, was frustrated at key intervals by a number of actors. Perhaps the most critical of these was the very institution that gave it life - the Supreme Court. As a result, although we have traveled fifty years from that momentous ruling, we, as a nation, have had less than half that time to actively work to achieve its covenant and ensure full equality of educational opportunities. The first part of this paper examines why the federal courts, the very institutions that gave the most hope for an integrated society, rendered the promise of Brown so elusive. The second part addresses how we as advocates might continue to pursue the goal of increasing educational opportunities for all, even in the face of the challenges that meet us today.

\section{The Road to Opportunity: The Elusive Goal of School INTEGRATION}

\section{A. Massive Resistance}

Nineteenth century civil rights leader Frederick Douglass said that "[p]ower concedes nothing without demand." evident than in the struggle to rid the public schools in the American South of the plague of state-enforced segregation. In the wake of the Supreme Court's decision, the power structure of the South, and indeed, every level of federal government, made few concessions in the struggle to revamp America's divided educational institutions. Under the guise of states' rights and local control, communities violently protested desegregation, and created wellorganized and well-funded resistance movements. White Citizens Councils, formed by prominent Southern bankers, doctors, lawyers, state legislators, and businessmen, exerted political and economic pressure on civil rights advocates. In 1956, every congressman and all but three senators from the eleven states of the old Confederacy signed the "Southern Manifesto" that pledged to overturn Brown. ${ }^{7}$ Meanwhile, the executive branch maintained public silence, while privately condemning the Supreme Court's decision and the seeming evisceration of "states" rights." "

\footnotetext{
6. Frederick Douglass Letter to an Abolitionist Associate, 1849, in Organizing For Social Change: A Manual For Activists In The 1990s (K. Bobo et al. eds., 1991).

7. See, e.g., Jack Greenberg, Crusaders in the Courts 213-17 (1994); Fred Powledge, Free AT LAST? 139-41 (1991).

8. President Eisenhower was a steadfast believer in the "functional" motives behind the doctrine of "separate but equal," as articulated in Plessy v. Ferguson, 163 U.S. 537 (1896). Therefore, he privately condemned the Court's ruling in Brown and promised Southern leaders that he would not enforce the decision with all deliberate speed, but would instead "make haste slowly." See, e.g., Kenneth O'ReIlLy,
} 
Perhaps most damaging, the High Court itself waited a full year to provide its directive on how to implement its ruling, and even then provided only the vaguest guidelines. ${ }^{9}$ Lower courts either interpreted Brown narrowly or agreed to delay desegregation plans due to threats of violence. This further empowered Southern schools to resist desegregation. ${ }^{10}$

In Prince Edward County, Virginia, one of the five companion cases included in the Brown decision, ${ }^{11}$ the school district went so far as to close public schools altogether rather than permit desegregation. ${ }^{12}$ These schools remained closed for five years. ${ }^{13}$ When a Virginia court declared the practice unconstitutional, the legislature repealed compulsory education laws and made school attendance optional. The Virginia legislature then enacted one of the earliest voucher programs, by allocating public monies for white students to use in attending private schools, so as not to have to attend schools with black children. ${ }^{14}$

It is no wonder then, that a full decade after the Brown decision, ninetyeight percent of black students in Southern states still attended fully

Nixon's Piano: Presidents and Racial Politics From Washington to Clinton 169-70 (1995). Eisenhower failed to take a position in almost all of the high-profile civil rights battles that occurred during his administration, including the Montgomery Bus Boycott, the battle to desegregate the University of Alabama, and the lynching of fourteen-year-old Emmett Till in Money, Mississippi, for allegedly whistling at a white woman. Id. at 171-72.

Indeed, the executive branch lacked any power to enforce Brown's mandate until the passage of the Civil Rights Act of 1964, which prohibited racial discrimination by any entity receiving federal funds. In 1969, President Nixon, whose campaign platform included opposition to desegregation orders, ended this exercise of power, leaving the duty to ensure compliance to the courts. $C f$. Adams v. Richardson, 480 F.2d 1159, 1164-65 (D.C. Cir. 1973) (observing the executive branch's lengthy delay in enforcing desegregation of institutions of higher education through Title VI).

9. See Brown, 349 U.S. at 300-01.

10. See, e.g., Cooper v. Aaron, 358 U.S. 1, 16-20 (1958) (holding that the Arkansas Governor, Orval Faubus, and the state legislature were bound by the Brown decision and must not delay implementation of a desegregation plan). The day before a desegregated Little Rock Central High was to open, Governor Faubus announced on television and radio that he had called out the Arkansas National Guard with directions to block black students' entrance to the schools; Faubus maintained that if black students attended school with whites, “'[b]lood [would] run in the streets." GreenBERG, supra note 7, at 229.

11. The other districts included Clarendon County, South Carolina; Wilmington, Delaware; Topeka, Kansas; and Washington, D.C.

12. S. Mitra Kalita, Reflecting on Lost Opportunities; School Closings During Massive Resistance Limited Black Virginians' Lives, WASH. Post, Mar. 4, 2004, at B1. This occurred in many school districts throughout the South. In Norfolk, Virginia, for example, 10,000 white and black students were shut out of public schools for several months in 1958. Mike Gruss \& Philip Walzer, Pioneers of Progress, VA.PILOT Star (Norfolk), Feb. 1, 2004, at A1.

13. Kalita, supra note 12 .

14. Id. 
segregated schools. ${ }^{15}$ The Southern power structure had conceded nothing, and the struggle to dismantle a system of racial hegemony continued. ${ }^{16}$

\section{B. Litigating for More Expedient Reform}

Such delaying tactics by school authorities necessitated a push by civil rights litigators to force clarification by the courts as to the meaning and contours of desegregation. While Brown I was revolutionary in its statement that "separate but equal has no place" in the field of public education, ${ }^{17}$ the Court essentially equivocated in Brown II, and failed to offer effective guidance on how to accomplish this goal. ${ }^{18}$ As such, civil rights attorneys pushed to create a legal framework that might bring the constitutional promise of Brown to bear on the harsh realities of racial inequities in America. In the late 1960s and early 1970s, civil rights attorneys brought a series of cases against individual school districts to push the Court's integration mandate. In 1968, some fourteen years after Brown, the Supreme Court held that freedomof-choice plans placed an undue burden on black schoolchildren, and were unacceptable where more expedient and effective methods of desegregation were available. ${ }^{19}$ Delay was "no longer tolerable," ${ }^{20}$ and the Court imposed an "affirmative duty" on school districts to eliminate the vestiges of discrimination "root and branch." 21 The Court explicitly identified the areas in which eliminating desegregation was of the utmost importance-student assignment, facilities, staff assignment, faculty assignment, extracurricular activities, and transportation. ${ }^{22}$

In 1971, the Court gave further contours to the meaning of equality in education in Swann v. Charlotte-Mecklenburg Board of Education. ${ }^{23}$ In that case, the Court granted district courts ample freedoms to fashion remedies to

15. Erica Frankenberg et al., A Multiracial Society with Segregated Schools: Are We Living the Dream?, 17 Civil Rights ProjeCt, Harvard Univ., available at http://www.civilrightsproject.harvard.edu/ research/reseg03/AreWeLosingtheDream.pdf (last visited Nov. 3, 2004).

16. The passage of the Civil Rights Act of 1964, prohibiting discrimination in all programs receiving federal aid, and authorizing the Department of Justice to sue on behalf of minorities if discrimination occurred, provided the government the enforcement powers necessary to begin a true dismantling of the apartheid system in American public schools. 42 U.S.C. § 2000c-2000d (2004).

17. Brown v. Bd. of Educ., 347 U.S. 483, 495 (1954) (internal quotations omitted).

18. Brown v. Bd. of Educ., 349 U.S. 294 (1955).

19. Green v. County Sch. Bd., 391 U.S. 430, 440-42 (1968).

20. Id. at 438 .

21. Id. at 437-38.

22. Id. at 435 .

23. Swann v. Charlotte-Mecklenburg Bd. of Educ., 402 U.S. 1 (1971). 
desegregate schools. ${ }^{24}$ These included court-mandated busing, the redrawing of attendance zone lines, and the use of mathematical ratios to ensure acceptable levels of desegregation. ${ }^{25}$ The Court also acknowledged the compounding effect that residential segregation had on educational segregation. ${ }^{26}$

In 1973, almost twenty years after Brown, the Court extended the mandate of desegregation to the North and West, where there had previously been no explicit statutes requiring segregation. In Keyes v. School District No. 1, Denver, Colorado, the Court held that in districts where school officials had instituted segregated schools in one area, the district had an affirmative duty to desegregate all the city's schools. ${ }^{27}$ The ruling also recognized Latinos' right to desegregation. ${ }^{28}$

Cases like Green, Swann, and Keyes signaled a high point in American jurisprudence, when federal courts actively examined remedial plans and the scope of the courts' remedial authority to achieve integration. These cases, decided between fourteen and twenty years after Brown, marked the zenith of the judiciary exercising its authority over the intransigent Southern power structure. Thus, well over a decade after the Court struck down statemandated segregation, the courts at last issued orders that forced school districts to expediently begin the task of making real the constitutional promise of equal protection. By defining the contours of integration in these key decisions, the Court precipitated a steady desegregation of American schools that continued, particularly in the South, for the next twenty years. ${ }^{29}$

\section{The First Wave of Judicial Retreat}

Unfortunately, this late-coming enforcement in the South was quickly followed by two opinions that sharply curtailed the flow of desegregation to

24. Id. at $12-17$.

25. Id. at $22-32$

26. Id. at 20-21. The Court found that planned segregation of schools led to segregated housing. Id.

27. Keyes v. Sch. Dist. No. 1, Denver, Colo., 413 U.S. 189, $203-05$ (1973).

28. Id. at 198. In that same year, a federal court held that the Department of Health, Education, and Welfare must issue enforcement proceedings against institutions of higher learning that failed to develop desegregation plans in compliance with Title VI of the Civil Rights Act of 1964. Adams v. Richardson, 480 F.2d 1159, $1165-66$ (D.C. Cir. 1973).

29. See, e.g., Gary Orfield \& Chungmei Lee, Brown at 50: King's Dream or Plessy's Nightmare?, 20 Civil Rights Project, Harvard Univ., available at http://www.civilrights project.harvard.edu/research/ reseg04/resegregration04.php (last visited Nov. 3, 2004). 
Northern metropolitan areas and diminished the remedies available to increase educational opportunities for low-income minority children. In 1973, a Supreme Court reshaped by four Nixon appointments severely curbed the judicial remedies available to low-income and minority students in educationally disadvantaged schools in its ruling in San Antonio Schools $v$. Rodriguez. ${ }^{30}$ In Rodriguez, the Court held that there is no fundamental right to an education in our nation, and that wealth is not a protected class; as such, there is no requirement that schools in richer and poorer areas receive equal funding. ${ }^{31}$

This decision marked a retreat from Brown's commitment to equality of educational opportunity. The Court refused to address the real issue in the case - whether a state scheme that allowed for educational funding disparities caused by variations in district property wealth was unconstitutionally discriminatory under the Fourteenth Amendment's Equal Protection Clause. ${ }^{32}$ Indeed, even before Brown, the Supreme Court had recognized that inequality in educational facilities may be a violation of the Equal Protection Clause..$^{33}$ In Rodriguez, however, the Court minimized the importance of financing variations to educational equity, even though the Equal Protection Clause is meant to address just such instances of "unjustifiable inequalities of state action." 34

The next year, the Court effectively ended the expansion of desegregation law, particularly for Northern and Western metropolitan areas. In the Milliken v. Bradley 5-4 decision, the Court struck down a desegregation plan in metropolitan Detroit and cited the importance of preserving local control of education..$^{35}$ The Court held that there could be no inter-district remedy absent a showing of an intentional inter-district violation. ${ }^{36}$ This holding signaled a significant departure from the Court's decision in Keyes only one year before. As in Keyes, the constitutional violation in Milliken was the intentional segregation of city schools. ${ }^{37}$ Yet, rather than ordering "all-out desegregation," 38 as it had done in Keyes, the Supreme Court precluded inter-

30. San Antonio Indep. Sch Dist. v. Rodriguez, 411 U.S. 1 (1973).

31. Id. at 54-55.

32. Id. at $55-59$

33. See Sweatt v. Painter, 339 U.S. 629, 633-34 (1950) (striking down state-enforced segregation of a law school). See also McLaurin v. Okla. State Regents for Higher Educ., 339 U.S. 637, 641-42 (1950).

34. Rodriguez, 411 U.S. at 89 (Marshall, J., dissenting).

35. Milliken v. Bradley, 418 U.S. 717, 752-53 (1974).

36. Id. at 752 .

37. See id. at 721

38. Keyes v. Sch. Dist. No. 1, Denver, Colo., 413 U.S. 189, 214 (1973). 
district relief, which was the only route to successfully desegregating the segregated schools in Detroit's urban core. ${ }^{39}$ The Court's decision to strike down such remedies allowed white flight to flourish, thus shaping the racial patterns of schools in metropolitan areas throughout the Northern and Western United States. These decisions also allowed the flowers of federalism, states' rights, and local control to start to bloom in the body politic once more.

In the companion case three years later, commonly known as Milliken II, a unanimous Court required states to fund remedial and compensatory education programs as part of the desegregation decree. ${ }^{40}$ Such decisions signaled a shift away from integrative remedies - they altered the nature of desegregation orders, and sought adequacy through remedial funding of segregated schools rather than pushing for an end to segregation.

\section{Retrenchment in 1990s Jurisprudence}

Although Supreme Court jurisprudence allowed desegregation to continue in the South, it was a mere twenty years after Swann that the Court sounded the death knell for the desegregative remedies there as well. In the 1990s, a conservative Court, led by Chief Justice Rehnquist, essentially relinquished its obligation to require school districts to remedy racial segregation. The Rehnquist Court ${ }^{41}$ issued a trilogy of opinions that severely limited the circumstances, means, and duration of desegregation remedies. While the Supreme Court had curtailed the financial equalization of schools and rejected metropolitan desegregation in its Rodriguez and Milliken decisions of the early 1970s, the Court dealt a deathblow to all desegregation remedies in the landmark decisions Board of Education v. Dowell, ${ }^{42}$ Freeman v. Pitts, ${ }^{43}$ and Missouri v. Jenkins. ${ }^{44}$

In Dowell, the Court held that once a "unitary" system could be established, a federal court's desegregation order should end, even if this meant a resegregation of schools. ${ }^{45}$ The Court held that a school board need only show it had complied in "good faith" and that "the vestiges of past

39. Milliken, 418 U.S. at $752-53$.

40. Milliken v. Bradley, 433 U.S. 267, 291 (1977).

41. While serving as a law clerk to Supreme Court Justice Jackson in 1952 and 1953, Rehnquist authored a memo stating that he believed "Plessy v. Ferguson was right and should be affirmed." See Richard Kluger, Simple Justice 606 (Alfred A. Knopf, Inc. 1976) (1975).

42. Bd. of Educ. v. Dowell, 498 U.S. 237 (1991).

43. Freeman v. Pitts, 503 U.S. 567 (1992).

44. Missouri v. Jenkins, 515 U.S. 70 (1995).

45. Dowell, 498 U.S. at 248-49. 
discrimination had been eliminated to the extent practicable." ${ }^{36}$ As such, the Court declared this Oklahoma school district to be unitary despite the fact that it remained segregated for a full seventeen years after Brown. ${ }^{47}$ In so doing, the Court disavowed any accountability for persistent racial injustice.

One year later, the Court reiterated in Pitts that "[r]eturning schools to [local control] at the earliest practicable date is essential to restore their true accountability in our governmental system. ${ }^{.48}$ To that end, the Court held that once a portion of a desegregation order is met, a federal court should cease efforts as to that portion and remain involved only as to those aspects of the plan that have yet to be achieved. ${ }^{49}$ This allowed for the piecemeal dismantling of desegregation orders across the South. The Court had failed to view the ramifications of segregated schools holistically. The six Green factors ${ }^{50}$ that had been devised to show school districts the areas in which they should focus desegregative efforts had now been subverted; they were being shown as the markers by which a district could make a piecemeal argument as to the "unitariness" of one particular area. Much as Brown's message that "separate but unequal has no place" has been undermined by present-day rhetoric that the ruling intended all programs to be color-blind, Green's message to desegregate in several key areas has been subverted by the Court's incremental "unitary" status determinations in Pitts. ${ }^{51}$

The Rehnquist Court dealt the final coup de grâce in Missouri v. Jenkins. $^{52}$ In an opinion distanced from historical reality, the Court established the requirement that lower courts must specify exactly what educational deficits are traceable to segregation and discrimination, and what results will be required as proof that the deficits are remedied. ${ }^{53}$ If such specification is absent, Jenkins gives courts license to return school districts to local control, thus allowing documented inequities to persist. ${ }^{54}$ Among other things, this opinion also released the state and local districts from paying for remedial programs. As Justice Ginsburg stated in her dissent, the Kansas

46. Id. at $249-50$.

47. Id. at 250-51.

48. Pitts, 503 U.S. at 490 .

49. Id. at 490-91.

50. The Court listed student assignment, facilities, staff assignment, faculty assignment, transportation, and extracurricular activities as the most critical areas with respect to desegregation. Green v. County Sch. Bd., 391 U.S. 430, 435 (1968).

51. Pitts, 503 U.S. at $490-91$.

52. Missouri v. Jenkins, 515 U.S. 70 (1995)

53. Id. at $100-03$.

54. Id. 
City metropolitan school district did not issue its first remedial order until three decades after Brown. ${ }^{55}$ Given such a firmly entrenched history of racial discrimination spanning more than two centuries, ${ }^{56}$ "to curtail desegregation at [that] time and in [that] manner [was] too swift and too soon." ${ }^{57}$

The lie behind this glorification of local control is similar to the Court's embracing of "color blindness" in many other contexts. It is a standard that treats whites and blacks as if they were similarly situated and ignores the history of segregation and its vestiges, which are such a unique and intrinsic thread in the American tapestry. Moreover, the Court's grim ruling goes beyond the damage caused by the curtailment of desegregative remedies in Milliken I. While Milliken hindered mandatory metropolitan desegregation efforts, Jenkins struck down a voluntary metropolitan school desegregation plan.

The opinions of the Rehnquist Court reflect a choice. The conservative majority of the Court chose to consider the constitutional harms suffered by minority students to be less significant than restoring the authority of local agencies to run schools free of federal oversight. The Court reiterated its desire to end federal court supervision and restated the common mantra of restoring control to local school systems. This very form of local control allowed segregation to flourish in the era before Brown, and has done so again in the decade since these decisions. ${ }^{58}$

\section{LESSONS LEARNED}

\section{A. The Results: Fulfilling Brown's Promise}

At the end of the day, we must remember that for the plaintiffs in Brown and the attorneys pleading their cases, the strategy of desegregation was ultimately about creating better educational opportunities for AfricanAmerican children, and for other similarly situated young people throughout the country. By this standard, Brown was a success in several respects. While substantial desegregation of students did not begin until fully seventeen years

55. Id. at 175-76 (Ginsburg, J., dissenting).

56. While the remedial programs at issue in Jenkins had been in place for only seven years, the state of Missouri has a long and well-documented history of racial subjugation, including slavery, slave-era "compulsory ignorance" laws forbidding the education of blacks, and state-sponsored racial segregation. Id. at 175-76.

57. Id. at 176 .

58. See discussion infra Part III.B. 
after the Court's decision in Brown - with Green and Swann-studies have shown substantial benefits in the academic achievement of African-American students attending desegregated schools. The most effective period of school desegregation took place from approximately 1970 until $1990,{ }^{59}$ when Dowell and its progeny prompted a rollback of desegregative gains. During that time, African-American students experienced a significant rise in academic achievement. In the 1950s, less than fifty percent of young African-American adults had a high school diploma or a GED. ${ }^{60}$ By 1993, the rate had increased to eighty-three percent, which was close to the completion rate of whites. ${ }^{61}$ By the late 1980s, the graduation rate for African-Americans surpassed the national secondary completion rates for most European societies. ${ }^{62}$

Likewise, the so-called "achievement gap" between African-American and white students decreased considerably. Reading, math, and science scores of elementary and secondary students improved between 1971 and the $1980 \mathrm{~s}^{63}$ This gap closed markedly, despite the fact that many lower-achieving African-American students who would have previously dropped out of school remained in the system. Moreover, scores for African-American students improved even though the incidence of poorer, single-parent families and unemployment were both on the rise. ${ }^{64}$ At least one study has found that

59. John R. Logan \& Deirdre Oakley, The Continuing Legacy of the Brown Decision: Court Action and School Segregation, 1960-2000, at 2 (Lewis Manford Ctr. for Comparative Urban Reg'l Research, Univ. at Albany Jan. 28, 2004), available at http://mumford.cas.albany.edu/ schoolsegregation/reports/Brown_report_1_28.doc. (last visited Nov. 16, 2004). As of 2000, seventy-five percent of African-American students in the South and sixty-two percent of African-American students in the rest of the country were attend ing schools in districts that were under mandatory desegregation decrees at some time between 1950 and 1964. Id.

60. Gary Orfield, Unexpected Costs and Uncertain Gains of Dismantling Desegregation, in Dismantling Desegregation 85 (Gary Orfield et al. eds., 1996).

61. Id.

62. Id. at 73,85 . One example of such change includes the St. Louis desegregation case, Liddell v. Board of Education, 567 F. Supp. 1037 (E.D. Mo. 1983). There, a settlement resulted in voluntary desegregation measures that allowed several thousand black inner-city youth to enroll in predominantly white systems in the suburbs. While the majority of transfer students were low-income, they completed high school at approximately twice the rate of their counterparts in racially isolated city schools and attended college at a rate three times above the national average for black high school graduates. AMY Stuart Wells \& Robert L. Crain, Stepping Over the Color Line: African-American Students in White Suburban Schools 198-99 (1997).

63. Kathryn Hoffman \& Charmaine Liagas, Status and Trends in the Education of BLACKS 48-52 (2003), available at http://www.nces.ed.gov/pubsearch/pubsinfo.asp?pubid=2003034 (last visited Nov. 3, 2004). Science scores for African-Americans appear to have remained constant beginning in the early 1990s. Id. at 53. The gap between reading scores of African-American and white students widened moderately beginning in the late 1980s until 1999. Id.

64. Orfield, supra note 60 , at 85-86. 
positive family changes, such as improved parental education, accounted for less than twenty-five percent of the reduction in the test score gap, and that significant changes in African-American educational opportunity brought by desegregation, the war on poverty programs, and affirmative action were most likely related to the improvement. ${ }^{65}$ In addition, the largest changes in the test score gap were seen in the Southeast, which experienced the highest levels of desegregation, and had the largest number of districts under mandatory desegregation decrees. ${ }^{66}$ African-American gains were the lowest in the Northeast, which experienced the least amount of desegregation, ${ }^{67}$ due to the Court's ruling in Milliken striking down mandatory inter-district desegregative remedies absent a showing of intentional discrimination.

In addition to the statistical evidence showing that desegregated schools lead to higher graduation rates and test scores, children derive other benefits from desegregation. Studies show that African-American children attending desegregated schools are more likely to enroll in and graduate from four-year colleges and major in subjects that lead to more lucrative jobs and professions. ${ }^{68}$ Studies have also shown that meaningful interaction between students of racially diverse backgrounds increases the likelihood that those students will grow up socializing across such boundaries and discussing racial matters. ${ }^{69}$

\section{B. Result of the Court's Abandonment of Desegregation Doctrine}

Yet, the Supreme Court's trio of opinions in the 1990s thwarted this integration process. These decisions have also made it even more challenging to address the manifold issues that have arisen in the school desegregation context, as well as the modern means that school districts and individuals have

65. Id.

66. LOGAN \& OAKLEY, supra note 59, at 2.

67. Id.

68. James McPartland \& JoMills Braddock II, Going to College and Getting a Good Job: The Impact of Desegregation, in Effective School Desegregation: Equity, Quality, and Feasibility 141, 144-51 (Willis D. Hawley ed., 1981).

69. See, e.g., Amy Stuart Wells et Al., How Desegregation Changed Us: The Effects of RaCially Mixed Schools on Students And Society (2004), available at http://www.tc.columbia.edu/ news/article.htm?id=4774\&tid=33 (last visited Nov. 3, 2004); William G. Bowen \& Derek BoK, The Shape of the River 231-34 (1998); Mitchell J. Chang, The Positive Educational Effects of Racial Diversity on Campus, in Diversity Challenged 175, 183 (Gary Orfield \& Michel Kurlaender eds., 2001). Even the Rehnquist Court, in Shaw v. Reno, noted that our Constitution encourages us to weld together various racial and ethnic communities, and to avoid racial balkanization. Shaw v. Reno, 509 U.S. 630, 648-49 (1993). See also Miller v. Johnson, 515 U.S. 900, 911 (1995). 
devised to evade court orders. In the wake of these rulings, cases sua sponte have returned to judges' calendars, with the expectation that the victims of the constitutional wrongs must prove that the vestiges of the segregated system exist, or face dismissal of the case. School districts that voluntarily sought to retain desegregation plans became subject to lawsuits from groups who opposed such plans, as was the case for the school district of the famous Swann v. Charlotte-Mecklenburg. ${ }^{70}$ Under Dowell, school districts need only show that they made "good faith" attempts to remove the vestiges of discrimination to the extent practicable, a nearly impossible standard for plaintiffs to disprove. ${ }^{71}$ Local institutions need only wrap their messages in the guise of "good faith" to show that they should be released from court supervision. As a result of the Court's latest desegregation rulings, if a largely segregated school system can point to any aspect of its system that is somewhat desegregated, or it can provide the message that existing segregation is the result of private housing choices, it may be granted partial or complete unitary status.

In essence, efforts to hold state and local institutions accountable for the effects of past discrimination have been hobbled by federal courts determining that the "fruits" of such discrimination fall too far from the proverbial tree; they are too attenuated to justify race-conscious remedies. Most importantly, and most ironically, courts have held that racially segregated systems are the product of private choices, rather than state action. ${ }^{72}$ Concerning the town of Gadsden, Alabama, one district court judge declared the school district unitary, finding that the level of interracial cooperation in Gadsden compared favorably with factional relations "in Kosovo and Northern Ireland," and

70. Belk v. Charlotte-Mecklenburg Bd. of Educ., 269 F.3d 305 (2001).

71. Bd. of Educ. v. Dowell, 498 U.S. 237, 249-50 (1991).

72. This is especially apparent in Justice Thomas's concurrence in Missouri v. Jenkins, 515 U.S. 70 (1995). He echoed a refrain from opinions of the nineteenth century when he mused that only stateenforced segregation was unlawful and that de facto segregation was neither inherently unconstitutional nor harmful to African-Americans. He noted that continued racial isolation may be the result of voluntary housing choices and other private decisions:

$[\mathrm{I}] \mathrm{t}$ is beyond the authority and beyond the practical ability of the federal courts to try to counteract these social changes. . . [ [N]eutral policies, such as local school assignments, do not offend the Constitution when individual private choices concerning work or residence produce schools with high black populations. The Constitution does not prevent individuals from choosing to live together, to work together, or to send their children to school together, so long as the State does not interfere with their choices on the basis of race.

Jenkins, 515 U.S. at 118, 121 (Thomas, J., concurring) (emphasis added)(citations and quotations omitted). 
stating that the school board cannot "require the lion to lay down with the lamb.,"73

This judicial philosophy is the same one that was embraced by the Court more than a century ago, in The Civil Rights Cases $^{74}$ of 1883, and in the notorious "separate but equal" decision of Plessy v. Ferguson. ${ }^{75}$ Like their nineteenth century predecessors, Dowell, Pitts, and Jenkins refuse to acknowledge historical reality. They fail to make even the most straightforward connections between the tenets of states' rights and federalism and the effects on the educational opportunities of children who have historically been denied such opportunities. They also fail to take account of historic and current patterns of residential and educational segregation ${ }^{76}$ or the impact of racial isolation on opportunities to learn and academic achievement.

73. Miller v. Bd. of Educ., No. 63-AR-574-M, slip op. at 9-10 (N.D. Al. Mar. 21, 2000). The Eleventh Circuit Court of Appeals subsequently reversed and remanded this decision. Miller v. Bd. of Educ., No. CD-12224, slip op. at 5 (11 th Cir. Aug. 8, 2001). The school district remains under a revised consent decree.

74. The Civil Rights Cases, 109 U.S. 3 (1883). In The Civil Rights Cases, the Court struck down the Civil Rights Act of 1875, which had outlawed racial segregation in public accommodations. After two centuries of systemized racial persecution in which state and federal resources were used to safeguard and maintain the institution of slavery, the Court determined that the "private wrong" of racial segregation in public accommodations was beyond the reach of the Fourteenth Amendment. It held that "[the Fourteenth Amendment] does not authorize Congress to create a code of municipal law for the regulation of private rights." Id. at 11 . Justice Bradley further argued that "[i]t would be running the slavery argument into the ground to make it apply to every act of discrimination which a person may see fit to make as to the guests he will entertain, or as to the people he will take into his coach or cab or car, or admit to his concert or theatre, or deal with in other matters of intercourse or business." Id. at 24-25.

75. Plessy v. Ferguson, 163 U.S. 537 (1896). Again, without an acknowledgment of the very recent history of slavery and present-day realities, the Court disregarded the purpose of the Fourteenth Amendment and concluded:

Legislation is powerless to eradicate racial instincts or to abolish distinctions based upon physical differences, and the attempt to do so can only result in accentuating the difficulties of the present situation. If the civil and political rights of both races be equal, one cannot be inferior to the other civilly or politically. If one race be inferior to the other socially, the Constitution of the United States cannot put them upon the same plane. Id. at 551-52.

76. See, e.g., Nancy A. Denton, The Persistence of Segregation: Links between Residential Segregation and School Segregation, 80 Minn. L. Rev. 795 (1996); Marc Seitles, The Perpetuation of Residential Racial Segregation in America: Historical Discrimination, Modern Forms of Exclusion, and Inclusionary Remedies, 14 J. LAND UsE \& ENVTL. L. 89 (1998). 


\section{Resegregation of America's Public Schools}

As a direct result of the Court's fair-weather treatment of the principles of educational opportunity for the dispossessed, we are now faced with a prodigious crisis in public education. In the fifty years since a unanimous Court signaled the promise of educational opportunity for millions of AfricanAmerican children, this ideal has been under sustained attack-first from unyielding school districts and local courts, and ultimately, from a reconstituted Supreme Court. The result of these attacks on efforts to desegregate has been the well-documented "resegregation" of school districts.

American public schools have been steadily resegregating for more than a decade ${ }^{77}$ dismantling the integrative successes of hundreds of districts that experienced significant levels of integration in the wake of Brown and its progeny. ${ }^{78}$ Such racial isolation in public schools is worse today than at any time in the last thirty years. ${ }^{79}$ Almost all of the nation's largest urban school districts are overwhelmingly nonwhite. ${ }^{80}$ These nonwhite schools educate one-sixth of the nation's African-American students and one-quarter of its Latino students. ${ }^{81}$ Yet, the most segregated of all students are white students. ${ }^{82}$

For those of us who litigate school desegregation cases today, we know that these statistics detailing school resegregation portend much more than a racial balkanization of schools at a superficial level. Beneath these statistics, the reality is that a disproportionate number of the schools that educate black and brown children also host ills that impede positive learning. As the old saying goes, "green follows white." The public schools that house the highest percentages of African-American and Latino students are also those that have concentrations of enormous poverty and very limited resources. ${ }^{83}$ In 2000 ,

77. See, e.g., Orfield \& Lee, supra note 29 , at 2-4.

78. During the period when the judiciary and the executive agencies actively enforced desegregation, from 1964 to 1970, the percentage of African-American students in white schools increased more than fourteen-fold in six years. Id. at 18. Indeed, from 1964 to 1974, the percentage of African-American students attending previously all-white schools increased from 2.3 percent to thirty-six percent. $I d$. at 19 . Over the next eighteen years, the increase in the number of African-American students in white schools was approximately thirty-three percent. $I d$.

79. See, e.g., Frankenberg et al., supra note 15, at 4-5.

80. Id.

81. $I d$.

82. On average, white students attend schools where eighty percent of the student body is white.

Id.

83. Roughly one-third of African-Americans live in poverty, compared to less than ten percent of 
nearly ninety percent of intensely segregated African-American and Latino schools had more than half of the students on free or reduced lunch. ${ }^{84}$ Conversely, ninety-six percent of white students are educated in schools with middle-class majorities. ${ }^{85}$ For those white students, this translates into better facilities, more computers, more experienced teachers, and a more diversified curriculum. For many students of color, this "green follows white" phenomenon may literally mean the difference between attending a four-year college and entering a lucrative profession, versus dropping out of high school with little hope of stable employment.

\section{The Current Face of Desegregation Litigation}

Abolitionist Wendell Phillips reminded us that the price of liberty is eternal vigilance. ${ }^{86}$ While Thurgood Marshall is no longer with us in body, his spirit and legacy permeate the work of those of us who continue to advocate for true equality in educational opportunity. We battle against the same forces of injustice, although the hydras with which we contend are more subtle. They are dressed up differently, but the issues have the same genesis-our nation's history of racial subordination and caste.

While many school districts are prematurely phasing out desegregation plans as a result of the Court's recent rulings, my colleagues and I continue to litigate a number of these cases. Such cases provide some of the only constitutional tools with which we may address a host of damaging issues that have evolved beyond the black and white school segregation of a generation

whites. Joseph Dalaker, Poverty in the United States: 2000, at 4 (U.S. Census Bureau 2001), available at http:www.census.gov/prod/2001pubs/p60-214.pdf (last visited Nov. 3, 2004).

84. Frankenberg et al., supra note 15, at 35.

85. Gary Orfield, The Growth of Segregation, in Dismantling Desegregation 53, 53 (Gary Orfield et al. eds., 1996).

The complex factors that have contributed to the crippling racial and spatial isolation of AfricanAmericans are rooted in this country's history of federal, state, local and private discriminatory housing and lending policies, and the continued effects of such policies. See, e.g., Arnold R. Hirsch, Making the Second Ghetto: Race and Housing in Chicago, 1940-1960, at 254-55 (1st ed. 1983); Kenneth T. Jackson, Crabgrass Frontier: The Suburbanization of the United States 196-218 (1985); Douglas S. Massey \& Nancy A. Denton, American Apar theid (1993); Melvin L. Oliver \& Thomas M. Shapiro, Wealth and Racial Stratification, in 2 America Becoming 241 (Neil J. Smelser et al. eds., 2001); Glenda G. Sloane, Creative Financing and Discrimination: Discrimination in Home Mortgage Financing, in A Sheltered Crisis: The State of Fair Housing in the Eighties 83, 83 -89 (U.S. Civil Rights Comm'n ed., 1983); Leland Ware \& Antoine Allen, The Geography of Discrimination: Hypersegregation, Isolation and Fragmentation Within the African-American Community, in THE STATE of Black America 2002, at 69, 69-89 (Lee A. Daniels ed., 2002).

86. See Wendell Phillips, Speeches, Lectures, and Letters 53-54 (1968). 
ago, but that nonetheless are vestiges of that racially segregated system. Ironically, the language of Brown assumed schools were effectively equal: "[T]here are findings below that the Negro and white schools involved have been equalized, or are being equalized, with respect to buildings, curricula, qualifications and salaries of teachers, and other 'tangible' factors." ${ }^{87}$ Yet, such equalization has remained elusive. Indeed, traditional desegregation cases are often used today as vehicles for the Plessy-like equalization of facilities, curricula, and other "tangible factors" that has yet to be achieved.

By obtaining and preserving consent decrees in school districts, we have also addressed a variety of issues that affect the holistic education of children in public schools. These include creating magnet programs, addressing racial disparities in the identification of special education students ${ }^{88}$ tackling the disproportionate disciplining of students of color, spurring new school construction, and improving the hiring and retention of African-American teachers and staff. In turn, these decrees help to diminish the effects of segregation, deconcentrate poverty, and improve the quality of learning for some children of color. In Alabama, for example, a recent statewide decree requires that the state address the vestiges of segregation that exist in the special education context. ${ }^{89}$ Through this desegregation decree, we have a vehicle to address some of the racial disparities that continue to plague students in these schools.

In the town of Gadsden, Alabama, the defendant school district filed multiple motions seeking a declaration of unitary status despite various indicators that the vestiges of segregation have not been eliminated. We have managed to keep several issues in the case open to ensure that the district properly addresses these issues. The district has done so in some areas. Significantly, after a long and protracted battle, the district has also agreed to construct a new high school complex that will educate all the public high

87. Brown v. Bd. of Educ., 347 U.S. 483, 492 (1954).

88. When Congress passed amendments to the Individuals with Disabilities in Education Act ("IDEA") in 1997, it found that students of color were statistically 2.3 times more likely to be identified as having special needs as their white counterparts. Individuals with Disabilities Education Act Amendments of 1997, Pub. L. No. 105-17, § 601(c)(8)(c), 111 Stat. 37, 41 (1997). See also Racial INEQUALITY IN SPECIAL EducATION (Daniel J. Losen \& Gary Orfield eds., 2002).

89. Lee v. Lee County Bd. of Educ., 963 F. Supp. 1122, 1124 (M.D. Ala. 1997) (holding Alabama State Board of Education and State Superintendent responsible for maintaining that system of education and requiring them to remove those vestiges). Parties entered into a statewide consent decree in the case in 2000, which requires removing the vestiges of racial discrimination in provision procedures for identifying and placing students in special education. See Marilyn Milloy, Truth in Labeling, NEA ToDAY, Jan. 2003, available at $\mathrm{http}: / / \mathrm{www}$. nea.org/neatoday/0301/cover.html. 
school students in this small town. This will open the doors of opportunity for all students in the district to take advantage of a more diversified curriculum and more experienced teachers.

In addition, by placing students in a more racially diverse environment, the new school will help break down the color barrier that continues to exist in the town's schools. When the idea of a consolidated high school was first raised in the town, more than one white parent voiced the sadly familiar refrain, "We don't want black children coming to our schools and lowering our standards." At the same time, the parent of a black student in the segregated black school told me that when her daughter inquired about a more challenging course not offered at her school, she was told by a white teacher, "You'll never be able to learn that." As the court aptly noted in Brown, school segregation helps foster a stigma that "may affect [children's] hearts and minds in a way unlikely ever to be undone." Wo While not a panacea, the creation of more racially diverse learning environments helps to decrease the invidious racial stigma that continues to saddle children in environments where such stark segregation lingers.

We are encouraged by our clients. They are almost exclusively in favor of courts retaining jurisdiction over many of these school districts, even though they may not all agree on the particular remedies that should be used. Indeed, many fear that absent the long arm of the law enforcing desegregation, students may be forever relegated to segregated learning environments in which white authority figures may tell them that they have no value.

In addition to our defense of mandatory desegregation plans, we have defended against attacks on voluntary desegregation programs in public schools throughout the country. School districts across the nation have voluntarily used race as one of many factors in creating holistic educational programs. Such voluntary measures can help to reduce racial isolation both within schools and between districts. In South Carolina and California, we have successfully defended policies in which school districts have voluntarily considered the racial diversity of student bodies in determining where to build new schools, how to draw attendance zone lines, and how to fashion student transfer policies. ${ }^{91}$

Advocates continue to bring affirmative action cases to target racial and socioeconomic isolation in public schools in the North, where school districts

90. Brown, 347 U.S. at 494.

91. See also Comfort v. Lynn Sch. Comm., 263 F. Supp. 2d 209 (D. Mass. 2003), rev'd No. 03-2415, 2004 WL 2348505 (1st Cir. Oct. 20, 2004). This case is currently scheduled for a rehearing en banc. 
may have never been subject to mandatory desegregation decrees. Such cases have been most successful in jurisdictions in which state law supports such theories. In Hartford, Connecticut, attorneys convinced the Connecticut Supreme Court that isolating low-income African-American and Latino students in poorly equipped schools in Hartford violated the state's constitutional guarantee of equal educational opportunity. The court held that affected students "suffer daily from the devastating effects that racial and ethnic isolation, as well as poverty, have had on their education." Connecticut Supreme Court required the state of Connecticut to reduce the "pervasive and invidious impact" of racial and ethnic isolation in Hartford and its surrounding twenty-one school districts. ${ }^{93}$ Using state law to impose an affirmative duty on metropolitan districts to desegregate, the decision rejected the Milliken standard that requires a finding of intentional segregation to mandate an inter-district remedy. Even this state court victory, however, requires constant vigilance. For while the Connecticut Supreme Court issued a clear directive to integrate and fully fund Hartford's poorer, segregated public schools, a recalcitrant state legislature failed to provide an expedient remedy. As such, parties only recently entered into a settlement, approved by the state legislature, which has begun to provide the relief dictated by the court years ago. Yet, when properly implemented, remedies such as the one devised in Sheff can marry integration with increased financial capital to provide student choice programs that increase racial and economic diversity within the public education system. ${ }^{94}$

92. Sheff v. O’Neill, 678 A.2d 1267, 1270 (Conn. 1996).

93. Id. at 1285 .

94. In the wake of San Antonio v. Rodriguez, a number of cases have used state constitutions to challenge funding disparities between public schools. In the first phase of such litigation, plaintiffs often challenged the failure of states to provide "equal" education, much like the theory put forward in the Rodriguez litigation. By the mid-1980s, however, courts struggled with developing a feasible definition of "equality," and grew increasingly reluctant to find in favor of plaintiffs in such cases. See, e.g., Michael A. Rebell, Education Adequacy, Democracy and the Courts 24 (Apr. 25, 2001), available at http://www. schoolfunding.info/litigation/litigation/php3 (last visited Nov. 3, 2004). As such, plaintiffs shifted their focus to "adequacy" claims, forcing states to provide an "adequate," "thorough," or "sound, basic" education for all students. Such a strategy has proven successful in at least seventeen state court cases. Id. While plaintiffs have seen success in the liability phase, however, state legislatures, which may be less willing or able to fund poorer districts at equal or equitable levels, have hindered success at the remedial phase. 


\author{
IV. The Future of Racial Inclusion
}

\begin{abstract}
"Discrimination in the opportunity to learn that is afforded a child must be our standard." 95
\end{abstract}

Fundamentally, the age-old debate about racial integration has never been simply about racial integration for the sake of white students and students of color being educated in the same classroom; integration has also been one of the only tools available to address overall concentrations of poverty and severe racial isolation, which hamper children's opportunities to learn. By providing increased access to quality education, schools may literally serve as the determinative factor of a child's success:

Today, education is perhaps the most important function of state and local governments. ... [I]t is a principal instrument in awakening the child to cultural values, in preparing him for later professional training, and in helping him to adjust normally to his environment .... [I]t is doubtful that any child may reasonably be expected to succeed in life if he is denied the opportunity of an education. ${ }^{96}$

In one of my cases, a parent who worked at the local steel mill told me that plant executives instituted a school in the plant for new workers hired from the town. When I asked why, he said that his employers started the school to teach the town's residents who came to work there some of the basic skills necessary to do their jobs. The employers felt that, "when the kids graduate from the local high school, we can't use them. They don't know anything." The town's high school graduates lacked such basic skills that, without remedial education, they could not handle the tasks required of them in the entry-level positions at the steel plant. While all children may not be bound for prestigious four-year colleges, all students have a right to be exposed to a quality education. In the long run, it is more expensive not to do so. ${ }^{97}$

95. San Antonio Ind. Sch. Dist. v. Rodriguez, 411 U.S. 1, 84 (1973) (Marshall, J., dissenting).

96. Brown v. Bd. of Educ., 347 U.S. 483, 493 (1954).

97. The United States now incarcerates more than 2.1 million people, the highest rate of any industrialized country. Many of those are non-violent offenders; they constitute seventy-two percent of admissions to state prisons. See Punishment and Prejudice: Racial Disparities and the War on Drugs, Human Rights Watch (May 2000), available at http://www.hrw.org/reports/2000/usa/ (last visited Nov. 3, 2004). 
The attack on school desegregation in the wake of the Supreme Court's ruling in Dowell and its progeny reflects the lack of financial and human capital that the public is willing to invest in our nation's public schools. Yet public schools are, quite literally, the training ground for the vast majority of American youth. In 2002, close to ninety percent of all students in elementary and secondary schools attended public schools. ${ }^{98}$ Thirty-five percent of these students were African-American or Latino. ${ }^{99}$ Therefore, we must invest in the future by investing financial and human capital in our public schools.

Part of this investment includes embracing the ideal of racial integration and diversity. Experiences like that of the young African-American girl who heard a teacher tell her she would never be able to learn exemplify the need to redouble our efforts to dismantle segregation and its true evil, racial stigma. By embracing diversity in public education, we also serve the overall educational and economic interest of our country. Our nation is becoming increasingly multiethnic. In 2001, the nation's schools were sixty percent white, seventeen percent African-American, seventeen percent Latino, four percent Asian, and one percent American Indian. ${ }^{100}$ By 2050, our country will no longer have a white majority. ${ }^{101}$ White students are expected to constitute forty-three percent of the nation's students, with the remainder being eighteen percent African-American, twenty-seven percent Latino, ten percent Asian, and one percent American Indian. ${ }^{102}$

In June 2003, the Supreme Court may have issued its most revolutionary statement on race and the importance of racial inclusion in the last thirty years. In Grutter v. Bollinger, the recent University of Michigan law school case, the Court upheld the use of race as a factor in an admissions policy, for the furtherance of racial and ethnic diversity. ${ }^{103}$ While this case specifically addressed the use of race in affirmative action policies in institutions of higher education, it may also help school districts defend race-conscious practices aimed at fostering diverse student bodies at the elementary and secondary level. The Court's ruling may be seen as a direct legacy of Brown's hopeful

98. School Enrollment—Social and Economic Characteristics of Students: October 2002 Dictated Tables, Table 5 Level of Enrollment Below College for People 3 to 24 Years Old U.S. Census Bureau (2002), available at http://www.census.gov/population/www/socdemo/school/cps2002.html (last visited Nov. 3, 2004).

99. More than ninety percent of all African-American and Latino students attended public schools in 2002. Id.

100. Lori Robinson et al., Strength in Numbers, THE CRISIs, Jan.-Feb. 2004, at 28.

101. $I d$.

102. Id.

103. Grutter v. Bollinger, 539 U.S. 306, 328 (2003). 
promise for an inclusive society. The Court, in fact, quoted directly from the Brown ruling in reaching its decision: "This Court has long recognized that "education . . . is the very foundation of good citizenship."'104 Indeed, "[e]ffective participation by members of all racial and ethnic groups in the civic life of our Nation is essential if the dream of one Nation, indivisible, is to be realized." ${ }^{105}$ In this way, Grutter represents the vehicle by which to keep the promise of Brown alive - using integrative policies to create and maintain access to equal educational opportunity.

Of particular import, the Court's ruling in Grutter went beyond the four corners of Brown, to say that successful integration is a necessity for the American economic system and for national security. ${ }^{106}$ This opinion reflected the truly diverse cross-section of individuals, public and private institutions, and organizations who came together with the common goal of preserving affirmative action. The Court acknowledged that the interest in true racial diversity is shared by many. ${ }^{107}$

In its opinion, the Court also acknowledged arguments made regarding the continuing struggle for racial equality. ${ }^{108}$ The Court acknowledged that there is a "unique experience of being a racial minority in a society, like our own, in which race unfortunately still matters."109 The Court clearly repudiated the idea cited by opponents of race-conscious programs that the legacy of Brown is color-blindness. This case has helped to reverse the trend that assumes a moral equivalent between the legacy of racial segregation and the use of race today to dismantle that legacy. As I continue to learn in my work each day, we cannot solve the issues of inequality by ignoring their existence. Rather, to make progress, we must continue to seek justice by righting the massive inequities we still see as a result of this country's tortured history of segregation and discrimination. ${ }^{110}$

104. Id. at 331 (quoting Brown v. Bd. of Educ., 347 U.S. 483, 493 (1954)).

105. Id. at 332 .

106. Id. at 330-31. "[M]ajor American businesses have made clear that the skills needed in today's increasingly global marketplace can only be developed through exposure to widely diverse people, cultures, ideas, and viewpoints. ... To fulfill its mission, the military ... must train and educate a highly qualified, racially diverse officer corps in a racially diverse setting." $I d$. (citations omitted).

107. Id.

108. NAACP Legal Defense and Educational Fund, Inc. Brief as Amicus Curiae in Grutter, available at http://www.naacpldf.org/content/pdf/gratz/grutter.pdf (last visited Nov. 3, 2004).

109. Grutter, 539 U.S. at 333.

110. In the wake of the Grutter decision, there has been significant discussion as to the meaning in Justice O'Connor's dicta that " 25 years from now, the use of racial preferences will no longer be necessary." Grutter, 539 U.S. at 343. Yet, this aspiration can only be achieved if we have a significant increase in the educational opportunities afforded children at the elementary and secondary level. Moreover, it can only 
We need a holistic approach to education that does not reduce a child's opportunity to learn to a few unrelated elements. Historically, it has never been about any one factor, but a combination of factors that improve education for all. These include breaking down racial isolation and the concentration of poverty. These also include partnering compensatory programs with programs aimed at structural desegregation remedies.

\section{CONCLusion}

The Abrahamic tradition defines faith as "the substance of things hoped for, the evidence of things not seen." "111 Those who fought for Brown and the dismantling of American apartheid hoped for a revolution. They envisioned a relatively quiet revolution in the South, whose reverberations would echo through school districts across our nation in a matter of years. Even Thurgood Marshall predicted that the Brown decision would result in the desegregation of schools within five years. ${ }^{12}$ Marshall and his colleagues believed in the inherent humanity of all of us. They believed it was possible to change the hearts and minds of segregationists, and undo the racial hegemony that constitutes the very fabric and foundation of American society. They could not have anticipated, however, that this call for humanity would meet with such sustained resistance from so many directions, including, ultimately, the institution that had issued the very mandate demanding apartheid's downfall.

The legacy of Brown is that it made possible the complete dismantling of American apartheid in various arenas well beyond education-including employment, housing, public accommodations, and criminal justice. Yet, complex challenges to educational opportunity, the continuance of historic discriminatory practices, and the development of new ones, all demonstrate the need for advocates to continue to work to create and maintain access to educational opportunities. As Albert Einstein once said, "the world is not dangerous because of those who do harm but because of those who look at it without doing anything." "113 We must inspire a commitment to quality public

be achieved if effective educational policy takes account of the continued salience of race in society, and its impact on educational, social, and professional opportunities. Indeed, since such race-conscious policies have been so frustrated in recent history, they have had precious little time to be effective. Thus, as Justice Ginsburg noted, "one may hope, but not firmly forecast, that over the next generation's span, progress toward nondiscrimination and genuinely equal opportunity" will obviate the need for race-conscious programs. Id. at 346 (Ginsburg, J., concurring).

111. Hebrews 11:1.

112. Richard Brust, The Court Comes Together, A.B.A. J., Apr. 2004, at 40, 44.

113. Albert Einstein, Tribute to Pablo Cassals (1953). 
education, and be willing as a society to invest in that. Likewise, our federal courts - the institutions that have thwarted both true financial and human investment in public education and efforts to open doors of educational opportunity at so many key points since Brown — should adopt the ideal the Supreme Court recognized in Grutter, and encourage action rather than apathy. For, as the past decade of resegregation has shown us, when the courts turn a blind eye, our nation's future becomes more dangerous by the moment. 